\title{
THE CRIMINAL ASPECTS OF AN INCOME TAX STRIKE
}

\author{
E. W. Puttrammer and Kenneth C. Sears*
}

1 HE dissatisfaction of taxpayers with greatly increased costs of government, in the face of greatly reduced tax-paying capacity, until recently showed a tendency to manifest itself in many varieties of tax-strikes. These movements ranged the gamut from highly organized, closely knit combinations for inaction to more or less widespread individual refusals to pay which were entirely or almost entirely independent of each other and were merely called forth at the same time by the same circumstances.

On the whole these strikes have probably had little success, at least on the surface, in bringing pressure to bear on the legislative or executive branches of the governments against which they were directed. Usually, too, they were abandoned before any serious question was raised as to the possible criminal liability of the participating taxpayers. It would be an interesting question what this criminal liability would have been in the event of a similar strike against the federal income tax, such a strike, by its terms, to continue until the federal budget (ordinary or extraordinary) was balanced. In view of the experiences of our local governments such a movement would not, until recently, have seemed unlikely. The federal budget is that one in which there is the greatest public interest, and the balancing of which is of the greatest importance. The federal income tax is probably the tax of widest incidence and greatest dramatic interest in the country. The combination of the two seems specially adapted to calling forth protests of this sort. What would have been their legality as a matter of criminal law?

The question divides itself into two parts. (I) Apart from any conspiracy angle, and considered only as an individual, isolated act, is the refusal to perform the obligations imposed by the tax law "legal," i.e., excusable or justifiable? Or, if an outright refusal is not, can it be so limited or qualified as to remain within the law and still attain the taxpayer's objective of applying pressure on the government? (2) Even if some sort of individual, disorganized, non-cooperative action (or inaction) could be devised which would be both legal and effective, would the element of cooperation, the

* Professors of Law, University of Chicago. 
banding together necessarily involved in a tax strike, itself constitute an offense under the conspiracy sections of the criminal code? In the discussion below these points will be considered in succession.

\section{ACTION BY A SINGLE TAXPAYER}

Conceivably the taxpayer might give effect to his opposition to the tax in any one of three forms of sabotage. (I) He might refuse to file any tax return at all, although he is one of those required by law so to do. (2) $\mathrm{He}$ might file a partial or incompleted return. (3) He might perform his duty in regard to filing a complete return but refuse to pay the tax which such a return disclosed him as liable to. In analyzing the statutory provisions bearing on the legality of these various forms of action outlined above it has been stated in general terms that:

The revenue laws . . . . carry stringent provisions for the punishment of persons, associations and corporations for not filing returns and paying their taxes. In such a case, the statutes involved should, and must be construed strictly in favor of the citizen. ${ }^{x}$

This injunction seems, however, to have lain very lightly on the courts, as the tendency very decidedly has been to resolve doubtful constructions or points in favor of the government, without practical interference by the rule just quoted. The attitude in fact adopted was stated more frankly and accurately in another case dealing with an earlier revenue act, but similar, so far as the present point goes:

Any act which the taxpayer might do.... where the effect and reasonable purpose would be to evade or defeat the tax, would constitute the offense. ${ }^{2}$

It is rather from this standpoint that the possible lines of conduct by the taxpayer will in all likelihood be judged.

I. Failure to File a Return. Two sections of the Revenue Act of I926 bear directly on a failure to file a return. One of these ${ }^{3}$ in broad terms makes any willful failure so to do a misdemeanor. No intent to defraud or to evade payment of a tax is necessary. The omission to act, knowing that

2 Alyea-Nichols Co. v. United States, I2 F. (2d) 998, 1002 (D.C.S.D. Ill. 1926).

2 United States v. Smith, ${ }_{3}$ F. (2d) 923 (D.C.W.D. La. I926). Italics supplied.

${ }^{3} 43$ Stat. 343 (r924), 26 U.S.C. A. $\$ 1265$ (I928): "Any person required under this title to pay any tax, or required by law or regulations made under authority thereof to make a return, keep any records, or supply any information, for the purposes of the computation, assessment, or collection of any tax imposed by this title, who willfully fails to pay such tax, make such return, keep such records, or supply such information, at the time or times required by law or regulations, shall, in addition to other penalties provided by law, be guilty of a misdemeanor and, upon conviction thereof, be fined not more than $\$ 10, \infty 00$, or imprisoned for not more than one year, or both, together with the costs of prosecution."

Reenacted in the Revenue Act of 1928,45 Stat. 835,26 U. S. C. A. \& $2 \mathrm{r}_{46} 6$ (a) (rg28). 
a return is required by law, suffices. The other section ${ }^{4}$ is more drastic. Willfully to attempt "in any manner to evade or defeat any tax imposed by this title" is made a felony. And the mere omission to file may, it has been held, be sufficient to constitute an "attempt to evade." Previous to this holding it might have been supposed that, as the former section expressly dealt with mere omissions to act, the latter section, in forbidding "attempts," must have been meant to refer only to positive efforts to evade, even if the word "attempt" does not intrinsically and always signify affirmative action. ${ }^{6}$ The court, however, did not thus restrict the felony section, but regarded it as partially at least overlapping the misdemeanor one.

Having closed the door to the argument that an omission cannot constitute an attempt, the court has dealt equally drastically with the argument that the felony section expressly applies only to those who "attempt" to evade or defeat the tax, and hence by its own terms is not applicable to those who succeed in their efforts, on the ground that such success has made the effort cease to be merely an attempt. Certainly in the usual use of the term an attempt suggests non-success, and where success has been attained the preliminary steps are not ordinarily thought of or described as an "attempt." It was held, however, that the word must here be interpreted as having a broader meaning. It must apply not only to those steps never crowned by success, but also to those preliminary acts or omissions which did in fact lead to an evasion. ${ }^{7}$ No doubt such a holding is entirely justified. Not only would the opposite view hold out a reward to the more successful law-breaker, but it would largely defeat any chance of successful prosecutions, as the best evidence of an intent to evade may well consist in there being a successful evasion. Justified as the court's holding is, it shows, however, how little reality there is in the asserted strict construction of these statutes in favor of the defendant.

443 Stat. 343 (I924), 26 U.S. C. A. § r266: "Any person required under this title to collect, account for and pay over any tax imposed by this title, who willfully fails to collect or truthfully account for and pay over such tax, and any person who willfully attempts in any manner to evade or defeat any tax imposed by this title or the payment thereof, shall, in addition to other penalties provided by law, be guilty of a felony, and, upon conviction thereof, be fined not more than $\$ 10, \infty \infty$, or imprisoned for not more than five years, or both, together with the costs of prosecution."

Reenacted in the Revenue Act of 1928,45 Stat. 835,26 U.S.C.A. § 2146(b) (1928).

5 O'Brien v. United States, 5 I F. (2d) r93 (C.C.A. $7^{\text {th }}$ I93r), certiorari denied, 284 U.S. 673,52 Sup. Ct. 129,76 L.Ed. 569 (193I).

6 This was the basis of the dissent of Alschuler, J., in O'Brien v. United States, supra note 5. 7 O'Brien v. United States, supra note 5. 
One further argument can be advanced for placing a limited scope on section I266. Its opening words refer to "any person required under this title to collect, account for, and pay over any tax"-language seemingly restricting it to fiduciaries. But the act proceeds "and any person who willfully attempts . . . . to evade." It has been held that the broad language of the latter passage is not restricted by implication to the narrower class just previously referred to, but applies to all tax evaders, whether fiduciaries or not. 8

In fact the breadth of the duty to file a return is shown not only in the scope of those cases holding a failure to file to be criminal-it is equally or even better shown in the narrowness of those holding a failure excusable. They are restricted to cases where the taxpayer personally believed, on reasonable grounds, that the income involved was not taxable. ${ }^{9}$ To the avowed tax-striker this loophole is of course wholly useless.

Given so broad a meaning to the criminal act, or rather omission, needed under the statute, it is to be expected that the courts will be similarly easily satisfied that a sufficiently blameworthy mental state or intent exists. This expectation is borne out by the cases and was foreshadowed by Beam v. Hamilton, ${ }^{\mathrm{x0}}$ a civil case brought by a taxpayer to recover a penalty paid under protest and originally assessed against him because of a failure to make a return showing certain taxable profits. In affirming a judgment by the district court, dismissing the plaintiff's action, the circuit court held that the government need not show any fraud on the taxpayer's part in order to entitle it to retain the penalty. The court stated:

The plaintiff was responsible for the source of [the figures] and sufficient details to insure a complete understanding of the business, and failure to take such precaution to discover the omission of the principal item of income does not constitute cause for failure to file ... a return.

In other words mere negligence without any fraud on the taxpayer's part is sufficient to put him in the wrong and to disentitle him to recover the penalty. Beam v. Hamilton was a civil case, it is true, but the court expressed itself in such broad terms as to indicate that this point would probably receive the same treatment in a criminal case. This inference is confirmed by United States v. Scharton, ${ }^{\mathrm{xx}}$ a criminal prosecution under the felony section ( $\$$ I266), where it was directly held that an intent to de-

${ }^{8}$ Ibid.

- United States v. LaFontaine, 54 F. (2d) 37 I (D.C.D. Md. 193I).

so Beam v. Hamilton, 289 Fed. 9 (C.C.A. 6 th I923). The passage quoted appears at p. 14.

II United Statess v. Scharton, 285 U.S. 5r8, 52 Sup. Ct. 4r6, 76 L.Ed. 9I 7 (r932). See also United States v. Commerford, 64 F. (2d) 28 (C.C.A. $2 d$ I933). 
fraud need not be averred, and that any such averment would be mere surplusage. ${ }^{\mathrm{x}}$

2. Filing a Partial or Otherreise Incomplete Return. The law being thus severe on the tax-liable person who, either willfully or negligently, fails entirely to cooperate, by failing to file any return at all, is a milder attitude adopted toward/one who files a partial or otherwise incomplete return? Such a one too is obstructing the easy and smooth working out of the tax laws involved, yet the difficulties which he creates are not so great as those produced by one who takes no action at all. By his partial return he does at any rate inform the government of his existence as a potential taxpayer. Should this slight amount of cooperation entitle him to more favorable treatment, or rather, to less drastic treatment? The attitude on this point has, commencing with early regulations by the Treasury Department, ${ }^{13}$ consistently been in the negative. Thus in Beam v. Hamilton, ${ }^{\mathrm{I4}}$ decided in I923, the court said:

We are unable to agree with the plaintiff's contention that, because Schedule B was so left blank, and plaintiff thereby (impliedly only) made a return that he was not engaged in a business with invested capital, and that he did not owe any excess profits tax, he thereby' made a return within the meaning of the excess profits title. ${ }^{\mathrm{x}}$ )

More recently, in a criminal case, ${ }^{76}$ the filing of a return showing income tax liability, but in an amount far below what a complete return would have disclosed, was held, when-shown to have been done with full knowledge, to constitute a willful attempt to evade the tax.7>This violation of the revenue laws, it should be added, is of course wholly separate from any

ra It is of course true, as the court recognizes, that in order to constitute an attempt, and as an integral part of the attempt, the action taken must be "willful," to "evade or defeat." In other words there cannot be an unintentional attempt or a negligent attempt, and the conduct whose effect is to evade or defeat must be "willful." If, in order to be "willful," it must (as would seem natural) be with knowledge that evasion will in fact probably follow, then the distinction between the wrongful intent which need not be alleged and the intent which must be alleged as part of the allegation of an "attempt" would seem to be very finely drawn, and any fact which was sufficient to show the conduct so "willful" as to constitute an attempt would necessarily also show that the conduct was engaged in with a full awareness that a tax evasion would result therefrom, and this latter is precisely the factual set-up which would be relied on to show an intent to defraud.

${ }^{13}$ Regulations, art." 407, quoted in I Montgomery, Income Tax (ed. of I927), 56.

${ }_{4}$ Beam v. Hamilton, 289 Fed. 9, 14 (C.C.A. 6th I923).

25 Italics supplied.

${ }^{26}$ Guzik v. United States, 54 F. (2d) 6I8 (C.C.A. 7th I932), certiorari denied, 285 U.S. 545, 52 Sup. Ct. 395, 76 L.Ed. 937 (I932).

${ }^{17} 43$ Stat. 343 (r924), 26 U.S.C.A. § I266 (I928). 
perjury that may be simultaneously committed, and as such each may, as a separate offense, be separately punished..$^{8}$

In the foregoing comments the incompleteness or partial nature of the return consisted solely in the absence of some of the required tax information, viz., the data on which the tax would be computed. Another form of incompleteness, and one, apparently, of a psychologically appealing nature, consists in the failure to swear to the return as filed. ${ }^{9}$ There appears to be the feeling, unreasoned more probably than thought out, that fair warning has been given that the taxpayer does not vouch for what he says and that he is not to be held accountable if, despite this, unwarranted reliance is placed in it. In a sense this is sound and logical. He has made his failure to cooperate with the tax-collecting authorities very clear. $\mathrm{He}$ has not left it to them to discover, as and if they can, that he is not fully cooperating. To this extent the failure to swear to the return does in fact appear to entitle him to more favorable treatment. But on the other hand the force of this argument is sharply limited. $\mathrm{He}$ is still a taxpayer who is withholding that aid which the government is entitled to ask of him. Whether this milder form of obstructionism calls for the same severity of treatment is another question, but that it too calls for repression by means of punishment seems obvious.

The argument that filing an unsworn partial return is no offense might, however, be raised in an at least verbally different manner. It might be contended that the word, "return," necessarily connoted an oath, that if not sworn to it was not a "return" at all, and hence could not be a false return. To this argument two answers can readily be made. In the first place, this argument proves too much. According to it no return has in law been filed at all. There is, then, a willful failure to file where the taxpayer knows that he is required to file. But a failure to act under such circumstances is itself a punishable evasion of the tax, as was discussed above. In the second place, no such limited meaning should be given to the word, "return." We are too familiar with its use with such qualifying adjectives as "sworn," and "unsworn," to attach to it now so limited a meaning as to have it signify only a sworn document. This was directly held in Emmich v. United States. ${ }^{20}$ The court there said:

${ }^{28}$ See United States v. Noveck, 273 U.S. 202, 47 Sup. Ct. 34I, 7 I L.Ed. 610 (r927) (under old statute, since repealed, however); Levin v. United States, 5 F. (2d) 598 (C.C.A. gth 1925), certiorari denied, 269 U.S. 562, 46 Sup. Ct. 21, 70 L.Ed. 412 (r925); Steinberg v. United States, 14 F. (2d) 564 (C.C.A. $2 d$ r926).

19 Witness the many unsworn personal property tax schedules which were formerly filed in Cook County (Chicago), Illinois.

20 Emmich v. United States, 298 Fed. 5 (C.C.A. 6th I924), certiorari denied, 266 U.S. 608, 45 Sup. Ct. 93,69 L.Ed. 465 (I924). 
We are not impressed with the limited construction that is attempted to be given to the statute, a construction that would make a false return under oath a violation of law, and a false return from which the oath by design or inadvertence has been omitted free of offense against the law. The .... return of the defendant, whether sworn to or not, was filed by him as his return, and intended to be received as such by the collector.

From the foregoing it would seem to be clear that the resistant taxpayer is on nearly as dangerous ground where he adopts the device of a partial return as he is where he wholly refuses to file.

3. Filing a Complete Return, but Refusing to Pay the Tax for Which Liability Is Disclosed. The Revenue Act specifies not only the time limit within which returns must be made, ${ }^{2 x}$ but also the time limit for making payment of the tax. ${ }^{22}$ In each case the statute specifies the general rule and then proceeds to name certain specific situations in which that general rule need not be lived up to, and where postponement and delay are permissible. Only one of these exceptions is here of even possible concern. The commissioner of internal revenue may grant a "reasonable extension of time for filing returns, under such rules and regulations as he shall prescribe with the approval of the Secretary." ${ }^{23}$ Likewise the commissioner "may extend the time of payment ... for a period not to exceed six months." It will be noticed that the power to postpone payment is absolutely vested in the commissioner, while his power similarly to postpone filing returns must be exercised subject to rules and regulations prescribed by him himself and approved by the Secretary of the Treasury. But regardless of whether the power is absolute or subject to review by the Secretary, it is hardly even remotely imaginable that such an extension would be granted for the sole purpose of enabling a taxpayer successfully to carry on a tax-strike. But even were such an extension so granted, its maximum limit is six months, a plainly inadequate period in which to make such a strike effective, unless the movement were participated in by a wholly unlikely proportion of the nation's taxpayers.

A direct refusal to pay promptly, where no extension has been granted, or where the extended time has elapsed, will, then, place the taxpayer in the wrong and will be followed by prohibitive penalties in the way of interest. ${ }^{24}$ May the taxpayer, however, as a final expedient, accomplish his purpose of resistance to the government, without undergoing direct or indirect punishment, by some form of payment in escrow, payment over to be made when the purposes of the tax-strike have been accomplished,

${ }^{2 x} 45$ Stat. 808 (I928), 26 U.S.C.A. $\$ 2053$ (I928).

${ }^{22} 45$ Stat. 809 (I928), 26 U.S.C.A. $\$ 2056$ (I928).

${ }^{23}$ The statute also provides that this extension may not exceed six months.

${ }^{24} 45$ Stat. 858 (Ig28), 26 U.S.C.A. $\$ 2294$ (a) (I928). 
with no provision for return payment to the taxpayer? If an independent escrow is selected, such as a bank or trust company, the increment of cooperation by the taxpayer has still further increased. By his action he has shown his good faith, if that term can be applied to a tax strike. He has definitely and permanently separated himself from the tax payment. $\mathrm{He}$ has devoted these funds to what he regards as a public purpose. But plainly even here he has not met his legal obligations. They can be met only by the payment contemplated by the revenue laws, a payment made to the local collector of internal revenue as agent for the federal government, as a consequence of which the funds so paid will be at the full disposal of that government. The transfer of funds to any other party and the keeping of any sort of restrictions on them, whatever else they may be, are certainly not a payment of the tax liability.

Only the cooperation evidenced by a full and correct return followed by full and prompt payment will accomplish the taxpayer's duties. Whatever the form taken by an income tax strike on the part of an individual, it may confidently be said that the federal government has fully protected itself against it by adequate statutory provisions.

\section{COMBINATION TO EFFECT INCONE TAX STRIKE}

Up to now consideration has been confined to a taxpayer's responsibilities as an individual. But an effective strike will mean almost certainly that many taxpayers must combine and undertake what are called "overt" acts. If this is done in order to avoid the payment of the federal income tax, for example, will the combining taxpayers be guilty of a conspiracy in violation of the federal penal code? It will be assumed, in order to put the question most favorably for the taxpayers, that the object of the particular taxpayers is to compel those responsible for the federal government to balance the budget, ordinary and extraordinary, or to restore the gold standard. Such an object many, if not most, citizens would consider to be meritorious or even essential to the welfare of the nation. Obviously if a tax strike with such a purpose is not free from criminality then one with less merit or motivated by base considerations cannot be justified.

The federal penal code ${ }^{25}$ has the following provision: "If two or more persons conspire either to commit any offense against the United States or to defraud the United States in any manner or for any purpose, and one or

${ }_{25} 2$ I Stat. 4 (I879), I8 U.S.C.A. $\$ 88$ (Criminal Code \$ 37) (I927). An agreement to refuse to pay taxes has received some attention in England, 3 Legal Observer I2 (1832); 6 Law Mag. 425 (I83I). 
more of such parties do any act to effect the object of the conspiracy, each of the parties to such conspiracy shall be fined not more than \$10,000 or imprisoned not more than two years or both." ${ }^{26}$ Will our supposed taxstrike violate that part of the above law which punishes a conspiracy "to commit any offense against the United States"? Absent any known decision which precisely answers the question we venture the opinion that there is no escape for those in the combination. They are guilty. The required intent, i.e., an actual intent not to pay the tax, is present despite the worthy motive, if it may be so described. An overt act, to effect the object of the agreement, upon behalf of at least one in the combination is assumed, and it has been demonstrated in preceding paragraphs that an act or omission in failing to pay an income tax by one not a party to any combination is criminal. The combination to effect what is criminal in one acting alone seems very clearly to be a criminal conspiracy under the federal criminal code. ${ }^{27}$ Of the very large number of federal cases dealing with criminal conspiracy a few will suffice to support this point of view.

I. Combination to Commit an Offense.-The very lengthy charge to the jury in United States v. Cassidy et al. ${ }^{28}$ explained the orthodox principle that the defendants violated the conspiracy statute, practically the same as the one set forth, supra, if they combined either to violate the statute

${ }^{26}$ For the history of the statute see United States v. Gradwell, 243 U.S. 476,37 Sup. Ct. 407, 6I L.Ed. 857 (I9I6); Thomas v. United States, $x 56$ Fed. 897 (C.C.A. 8th I907).

${ }_{27}$ In United States v. Rachmil, 270 Fed. 869 (D.C.S.D. N.Y. I92I), Bloom et al. had been acquitted of a conspiracy under Section 37 to commit an attempt willfully to defeat and evade the income tax law. Then they were indicted for willfully attempting to evade the same law. Bloom's motion to quash the second indictment was sustained. Knox, D.J., said at page $87 \mathrm{I}$ : "Inasmuch, however, as the Income Tax Law itself makes an attempt to evade its provisions a crime, it would seem not to be necessary to make frequent resort to Section 37 in order to overtake wrongdoers upon the threshold of their transgressions. I do not mean to say that resort to Section 37 may not be had; circumstances are conceivable where such action would be the part of wisdom and in the public interest. Neither do I mean to hold that a verdict of not guilty upon a conspiracy charge necessarily forecloses a further prosecution for the substantive offense. . . . The parties might have conspired to violate the law, and have done things in pursuance of such conspiracy which in and of themselves could by no manner of means constitute an attempt to violate the law. Suppose, for example, that the parties had orally agreed to violate the law, and that thereafter one of the parties visited one of his co-conspirators for the purpose of discussing details of the conspiracy. Such action upon the part of one of the conspirators would constitute an overt act; but none would contend, I think, that the mere agreement and the subsequent discussion of details would constitute an attempt to violate the taxing statute. What was done up until this time would fall short of an attempt. The parties might, before actually attempting to violate the law, withdraw from their unlawful agreement -such withdrawal, however, an overt act having, as above suggested, been committed, would not make them immune from successful prosecution under the conspiracy statute."

${ }^{28}$ United States v. Cassidy et al., 67 Fed. 698 (D.C.N.D. Cal. 1895 ). See also Walter v.

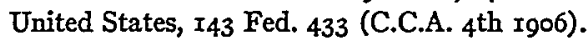


forbidding an obstruction to the passage of the mail or to violate the statute forbidding restraint of trade among the several states. Both statutes had criminal provisions. The maximum penalty for a violation of the first statute was a fine of $\$ 100$; but a conspiracy to violate it could be punished by a fine of $\$ 10,000$ and by imprisonment for two years.

The orthodox principle would seem to contemplate, however, that a prosecution for a criminal conspiracy under that part of the federal act that is being considered here will fail if the object of the agreement is action that those in the combination may undertake without committing any federal offense. Accordingly the prosecution in Fain et al v. United States ${ }^{29}$ was unsuccessful. There was an attempt to convict the defendants of conspiring ( $I$ ) to procure and hold for sale relinquishments by homestead entrymen and (2) to institute pretended contests of homestead entries for the purpose of preventing the lands covered by them from being entered by other qualified entrymen until they could sell their relinquishments for their own benefit. It was held that these acts, under the facts of the case too complicated for recital here, could be done lawfully under congressional legislation. There was no decision whether the same persons were guilty for conspiring to make a false homestead entry.

United States v. Foster ${ }^{3 \circ}$ seems also to be an approval by the Supreme Court of the orthodox principle. The district court sustained a demurrer to the indictment in two counts on both aspects of the conspiracy statute. The theory of the district court apparently was the same as that specified in Fain et al. v. United States, supra, i.e., Foster's conduct "was to secure for him[self] only what he was legally entitled to receive." Therefore he committed no crime and as a consequence there could be no conspiracy to commit a crime. With this analysis the Supreme Court, in a unanimous but not very clear opinion, disagreed. The holding seems to be that the indictment was valid as a charge for conspiring to violate a specific section of the criminal code, to-wit section 206. Perhaps the indictment was also sustained on the basis of that part of the conspiracy statute which forbids a conspiracy to "defraud the United States."

Despite the rule concerning strict construction of criminal statutes the word "offense" in the federal conspiracy statute has been given a liberal interpretation. In United States v. Hutto ${ }^{3 \mathrm{x}}$ the indictment charged a conspiracy to commit an offense against the United States; that the defend-

29 Fain et al. v. United States, 209 Fed. 525 (C.C.A. 8th I9r3).

${ }^{30}$ United States v. Foster, 233 U.S. 515, 34 Sup. Ct. 666, $5^{8}$ L.Ed. ro74 (1913).

${ }^{3 x}$ United States v. Hutto, 256 U.S. 524, 4I Sup. Ct. 54I, 65 L.Ed. I073 (I92I). See also Biskind v. United States, 281 Fed. $47^{\circ}$ (C.C.A. 6 th I922) and Taylor v. United States, 2 F. (2d) 444 (C.C.A. $7^{\text {th }}$ 1924). 
ants conspired to violate a federal law, section 2078 , prohibiting any person employed in Indian affairs from having any interest in any trade with Indians except for the United States. The Supreme Court reversed the action of the district court in sustaining a demurrer to the indictment. For one thing the latter court held that section 2078 in providing only a "penalty" of $\$ 5,000$ and removal from office had not prescribed an "offense" against the United States; that the United States was confined to a civil action to recover the penalty. The Supreme Court assumed this to be true, for the sake of argument, but held that such a penalty was included in the word "offense" within the conspiracy statute.

A step in advance of the Hutto case was taken by Wham, D. J., in United States $v$. Winner et al. ${ }^{32}$ The defendants were charged in a second count with conspiring to commit an offense against the United States by counterfeiting a patented article in violation of an act of Congress providing "for every such offense . . . . a penalty of not less than \$IOO with costs; one-half of said penalty to the person who shall sue for the same, and the other to the use of the United States." Even though this was only a provision for a qui tam action instead of a criminal prosecution, and even though the federal government could not institute the action to recover the penalty, still the demurrer to the second count was overruled. The court gave careful consideration to previous decisions pro and contra and then followed the point of view announced briefly and perhaps even casually in the $B$ utto case. If the act is prohibited "in the interest of the public policy of the United States," that is an "offense" within the general statute dealing with conspiracies set forth supra. The second count in this prosecution was also held valid by the circuit court of appeals for the seventh circuit in a brief per curiam opinion. ${ }^{33}$

The Winner and Hutto cases very recently have come under consideration in U.S. v. Brozen et al. ${ }^{33 a}$ There the defendants were indicted under the first clause of section 37 of the criminal code for a conspiracy to commit an offense against the United States. More particularly, they were accused of combining to violate sections 84 and 93 of title I2 U.S.C.A. These sections after prohibiting with qualifications a national banking association from lending more than ten per cent of its capital to any one person, provide, that ". . . . every director . . . . shall be held liable in his personal and individual capacity for all damages which the association, its

32 United States v. Winner et al., 28 F. (2d) 295 (D.C.N.D. Ill. I928); 77 Univ. Pa. L. Rev. 535 (I929); 42 Harv. I. Rev. 574 (I929).

33 Winner v. United States, 33 F. (2d) $5 \circ 7$ (C.C.A. 7 th $x 929$ ).

332 United States v. Brown et al., 6 F. Supp. 33I (D.C.W.D.Ky. I933). 
shareholders, or any other person, shall have sustained in consequence of such violation." A demurrer to the indictment was sustained. The district judge was of the opinion that this situation was not controlled by the Hutto and Winner cases; that the statutes violated in those cases provided penalties; that, in the case before him, no penalty had been provided; and that section 93 was "simply a statutory enactment of a common-law liability to recover civil damages for the amount of the loss and very likely for any additional damages flowing therefrom." Thus, it appears, that the line of development which the first clause of section 37 has taken has come to the place where one debate will turn on whether a statute is penal or merely one allowing damages. How shall we classify a statute which provides for a forfeiture as is the case in the first part of section 93? Is such a forfeiture within the meaning of the word "offense" in the conspiracy statute (section 37)? Perhaps an opportunity was overlooked in the Brown case. Another debate may be whether a particular statute was enacted "in the interest of the public policy of the United States." It was not argued in the Brown case that sections 84 and 93 were enacted otherwise than "in the interest of the public policy of the United States." Indeed no direct utterance on this proposition appears in the opinion. A reading of section 93 will disclose that for violations of section 84 two remedies are provided. The first is a suit for the forfeiture of the franchises and dissolution of the banking association. The court was silent as to the significance of this provision. The second is the action for "all damages," heretofore mentioned. The nature of the first remedy would appear to support the notion that the second remedy is for the advancement of a national public policy. It may be an answer to this, however, to argue that the second remedy was not solely a matter of public policy because the persons injured, not the public, keep the damages. Against this answer can be cited the Winner case where the informer gets the benefit of half of the penalty. Perhaps, however, the latter will be regarded as a reward for his trouble in becoming an informer.

One of the rulings in United States v. Galleanni et al..$^{34}$ marks a more advanced position than the Winner case, but in our opinion the particular holding can hardly be justified. The defendants were indicted in counts one and three for a conspiracy to violate the Selective Draft Act in that they published a statement in a newspaper to procure persons subject to the draft to commit an offense against the United States by willfully failing to register as required by section 5 of the draft act. Morton, D. J., admitted that the conspiracy was a mere solicitation and that "no statute

34 United States v. Galleanni et al., 245 Fed. 977 (D.C.D. Mass. I9I 7 ). 
of the United States makes such solicitation criminal." Nevertheless he overruled a demurrer to these counts. His argument was that a willful failure to register was an "aggravated offense" and that the defendants' conduct was a "common law crime," i.e., a solicitation. Then he asked himself "whether a conspiracy to commit that which would be at common law an offense against the United States, but which is not alleged to be a fraud on the United States, and is not made a crime by any federal statute, is punishable under section 37 ," the general conspiracy statute here under consideration. His answer was affirmative, relying on In re Coy. ${ }^{35}$ In the first place it appears to be curious to reason on the basis of "that which would be at common law an offense against the United States" when the United States does not recognize common law offenses as a part of its criminal law..$^{36}$ In the second place we venture to distinguish, even though Judge Morton stated that he was unable to distinguish, the Coy case. In that case there was a prosecution under the conspiracy statute for a violation of specific federal statutes which assumed and adopted the laws in force in various states for the conduct of elections wherein there was voting for a member of the national House of Representatives. The situation is rather complex in that the federal statutes in the main are very general and leave to the states the problem of providing for the election machinery and the personnel to operate it; but the indictment was based on the fact that a federal statute made it a crime for any person to interfere "in any manner with any officer of such election in the discharge of his duties." Can there be any real difficulty in distinguishing, without additional consideration, such a case from United States v. Galleanni et al., where it was admitted that the conspiracy was to commit that which was not a crime by any federal statute? It is true that the position of the federal courts that there are no common law crimes in the federal system came about more or less by default and it has been questioned in an official manner. ${ }^{37}$ However the doctrine came to be accepted and it has prevailed so long that the chances are that the decision in the Galleanni case on counts one and three will not be followed. If it proves to be otherwise, it would appear to be the beginning of the end of the familiar notion that crimes against the federal government must be statutory. In this connection it should be observed that there was no attempt by Judge Morton to argue that the conduct of the defendants, even though not an agreement

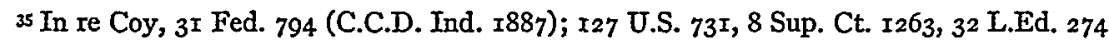
(I888).

${ }^{36}$ See United States v. Gradwell, 243 U.S. 476,37 Sup. Ct. 407,6 I L.Ed. 857 (rgr6) and cases cited.

${ }^{37}$ See Ex parte Grossman, 267 U.S. 87, 45 Sup. Ct. 332, 69 L.Ed. 527 (I925). 
to commit a crime, was an agreement to commit an "offense," i.e., an act prohibited by the public policy of the United States. Broad as the Winner case, supra, may be, nevertheless in that case there was an agreement to violate a specific federal statute..$^{38}$

2. Combination to Defraud. - There remains to be considered whether a combination to avoid the payment of income taxes, to continue our example, will violate the other part of the federal conspiracy statute, to-wit, "to defraud the United States in any manner or for any purpose." Here, also, the interpretation usually has been liberal instead of strict, despite the fact that the statute is criminal. ${ }^{39}$

In United States v. Curley ${ }^{40}$ it was argued on demurrer that the above clause as well as a similar expression in another section dealing with forgery should be limited to "direct pecuniary fraud by depriving the United States of money or property." The demurrer was overruled by the district judge not without some doubt. A conviction was affirmed by the circuit court of appeal in an opinion of unnecessary length. ${ }^{4 \mathrm{I}}$ It was argued that the fraud clause included "conspiracies to impair any of the functions of the government." For the sake of completeness it was also stated that the conspiracy proved in the particular case was one to defraud the government of a salary and this fact justified a holding that the conduct was within the second clause of the general conspiracy statute by the most orthodox sort of reasoning. Thus it happened that there was established a precedent that a conspiracy to defraud existed when Hughes conspired with Curley that the latter would impersonate the former at a civil service examination in order to secure for Hughes a position within the federal classified civil service.

In United States v. Moore et al. ${ }^{42}$ a demurrer to an indictment under the fraud section of the conspiracy statute, supra, was overruled. The defendants were accused of combining to administer corruptly for their own advantage an appropriation law of Congress providing for the survey of agricultural lands by seeking to survey arid land not suitable for agriculture. In a careful opinion, Wolverton, D. J., held that the pleader appropriately

\footnotetext{
${ }^{38}$ Observe this statement in United States v. Lyman, Igo Fed. $4{ }_{4}$ (D.C.D. Ore. IgII): "To constitute the crime of conspiracy, the object of the unlawful agreement must be the commission of some offense against the United States in the sense only that it must be some act made an offense by the laws of the United States." What is meant by "laws"?

39 Cf. a dictum to the contrary in United States v. Robbins et al., 157 Fed. 999, I000 (D.C.D. Utah I907).

10 United States v. Curley, 122 Fed. 738 (C.C.D. Mass. 1903).

1" Curley et al. v. United States, I3० Fed. I (C.C.A. Ist 1904).

12 United States v. Moore et al., I73 Fed. I22 (C.C.D. Ore. Igog).
} 
might have charged the defendants with conspiring to defraud the government of its public moneys, but that he chose to charge the defendants with the maladministration of the law and "upon this last theory of the charge I hold the indictment good."

The point of view of the Curley and Moore cases was approved by the United States Supreme Court in Haas v. Henkel. ${ }^{43}$ Therein was considered an indictment under both clauses of the conspiracy statute. The combination sought to obtain advance knowledge of the statistics on the cotton crop, gathered at much expense by government employees, for the purpose of speculation on the cotton market. The indictment sufficiently charged a conspiracy to defraud the United States, said the court, to require the removal of one defendant to the District of Columbia for trial. The decision was deprived of some value for present purposes by the declaration of the court that "it is clear that practices of this kind would deprive these reports of most of their value to the public and degrade the department in general estimation, and that there would be a real financial loss." However it was admitted that the indictment alleged no direct pecuniary loss to the United States and the court uttered the following for which, it seems, the case is chiefly cited:

But it is not essential that such a conspiracy shall contemplate a financial loss or that one shall result. The statute is broad enough in its terms to include any conspiracy for the purpose of impairing, obstructing or defeating the lawful function of any department of government.

Then the court considered the counts charging a conspiracy to commit an offense against the United States but there was no clear ruling as to their validity.

Since the decision in Haas v. Henkel, to say nothing of an earlier day, it has been regarded as settled law that there can be a conspiracy to defraud under the federal statute even though no property of the United States was directly involved. Since, however, almost any activity or function of the federal government involves property or pecuniary outlay in some form it is perhaps too much to expect a decision that sustains a conspiracy to defraud which has nothing whatsoever of the property aspect. In any event the point of view in the Curley opinion, as approved by the Supreme Court, has been followed in many subsequent cases. ${ }^{44}$

43 Haas v. Henkel, 216 U.S. 462 , 30 Sup. Ct. 249, 54 L.Ed. 569 (Ig०g).

44 Some of them follow, and in a number of them the indictment was based upon both clauses of the general conspiracy statute: United States v. Plyler, 222 U.S. I5, 32 Sup. Ct. 6 , 56 L.Ed. 68 (rgIr) (not a conspiracy prosecution); United States v. Walter, 263 U.S. r5, $_{44}$

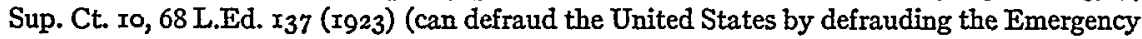


Finally the interpretation of the conspiracy statute met with a limitation. In Hammerschmidt et al. v. United States, 15 the Supreme Court reversed the conviction which had been affirmed in the circuit court of appeals. ${ }^{46}$ Haas $v$. Henkel, was explained and distinguished and it was ruled that it is not a conspiracy to "defraud" the United States by openly conspiring to procure, by means of printing handbills, etc., persons subject to

Fleet Corporation); United States v. Aczel, 2Ig Fed. 9I7 (D.C.D. Ind. I9I5), I5 Col. L. Rev. 544 (IgI5) (".... it is perfectly plain that a conspiracy which is calculated to obstruct and impair, corrupt, and debauch an election where Senators and Representatives in Congress are to be elected, would be to defraud the United States by depriving the government itself of its lawful right to have such Senators and Representatives elected fairly and in accordance with the law"; but even here the annual salary of a member of Congress will serve as the property element if such is required; United States v. Gradwell, 234 Fed. 446, (D.C.D.R.I. I9r6), 243 U.S. 476,37 Sup. Ct. 407 , 6r L.Ed. 857 (I9I6), contra, the conspiracy statute in question was never intended to apply to elections); United States v. Galleanni et al., 245 Fed. 977 (D.C.D. Mass. I917) ("the United States was entitled to have persons subject to registration [draft for military service] perform their duty and register according to law; and a conspiracy to prevent their doing so was a conspiracy to deprive the United States of a right to which it was entitled, and therefore to defraud it, within the meaning of Section 37 "; this opinion was on demurrer to the indictment and the facts are not fully stated; it may be inconsistent with the later decided Hammerschmidt et al. v. United States, 265 U.S. I82, 44 Sup. Ct. 5II, 68 L.Ed. 968 (1924); see Denison's dissenting opinion in 287 Fed. 825 (C.C.A. 6th I923); Hamburg-American etc. Co. v. United States, 250 Fed. 747 (C.C.A. 2 d I9I8) (conspiracy to defraud the United States by obtaining clearances by means of false manifests etc.); Firth et al. v. United States, 253 Fed. $3^{6}$ (C.C.A. 4 th r9r 8) (similar to the Galleanni case, supra); United States v. Slater et al., 278 Fed. 266 (D.C.E.D. Pa. I922) (conspiracy to defraud the United States by a combination to defeat the purpose of the National Prohibition Act); Wolf et al. v. United States, 283 Fed. 885 (C.C.A. 7 th r922) (avoiding governmental inspection of goods made under contract with the United States). Henry et al. v. United States, 15 F. (2d) 624 (C.C.A. gth I926) (conspiracy to procure the execution and approval of fraudulent bail bonds); Falter v. United States, 23 F. (2d) 420 (C.C.A. 2 d 1928) (defeating the right of the United States fully to contract and assert its dominion as an owner; property loss was clear however); Miller v. United States, 24 F. (2d) 353 (C.C.A. 2d I928) (the United States was defrauded "of its right to have disinterested and conscientious service and out of property of which it had possession and dominion, and to which it had power to assert and maintain title"); Wallenstein et al. v. United States, 25 F. (2d) 708 (C.C.A. 3d r928) ("conspiracy to defraud the United States in the exercise of its governmental function" of regulating intoxicating liquors); Cendagarda v. United States, $64 \mathrm{~F}$. (2d) I82 (C.C.A. Ioth I933) (conspiracy to have another plead guilty to a violation of the National Prohibition Act).

The following cases should be consulted as to the meaning of a "lawful function" of the federal government: Sales v. Unites States, 234 Fed. 842 (C.C.A. $2 d$ I9r6); Krichman v. United States, 263 Fed. 538 (C.C.A. 2 d r920); Keane v. United States, 272 Fed. 577 (C.C.A. $4^{\text {th }}$ I92I); Rembrandt v. United States, 28I Fed. 122 (C.C.A. 6th I922); Browne v. United States, 290 Fed. 870 (C.C.A. 6 th I923).

45 Hammerschmidt et al. v. United States, 265 U.S. I82, 44 Sup. Ct. 51I, 68 L.Ed. 968 (r924).

${ }^{46}$ Hammerschmidt et al. v. United States, 287 Fed. 817 (C.C.A. 6th I923), Denison J., dissenting. 
the draft to refuse to obey the draft law; to violate the statute there must be an obstruction of the government in one of its lawful functions "by deceit, craft or trickery, or at least by means that are dishonest"; open defiance of the government is not to defraud. This may seem to mean that those in our supposed combination to avoid paying income taxes until the two budgets are balanced will escape conviction under this particular clause of the general conspiracy statute by indulging in an open defiance of the federal government and by avoiding all deceit and dishonesty. However this is not clear. The combination aims at the finances of the United States; the pressure is on "property" and when this is the case those in the combination need not be surprised if the Supreme Court should hold that a conspiracy to "defraud" the United States out of the collection of taxes applies as well to open defiance as to deceitful practices; that the Hammerschmidt case, in turn, is limited to a "lawful function" other than that which is in a dominant sense money or property. ${ }^{47}$

In this connection United States $v$. Cohn ${ }^{48}$ demonstrates that the expression "defrauding the United States" is used in more than one way. There occurred a prosecution under a different provision, to-wit, section 35, punishing the falsification of any fact "with the intent of cheating and swindling or defrauding" the United States. But it was held that this section did not prohibit the wrongful obtaining of non-dutiable goods from a collector of the United States; that "defrauding" in this section was used only in its usual and primary sense of causing pecuniary or property loss and not in the secondary sense of obstructing one of the lawful governmental functions as under section 37. But so far as known no decision has decided that "to defraud" under section 37 is limited to the secondary sense just mentioned; indeed the contrary has been assumed. To deprive the government of revenue is to cause a pecuniary loss. So, the only question is whether such a deprivation through combination by open defiance is "to defraud." As to that, the Hammerschmidt case may be suggestive but hardly conclusive that only deceitful or dishonest conspiracies are forbidden by the second clause in the general conspiracy statute (section 37) regardless of any possible distinction whether the conspiracy affects "property" or a mere "function" of government.

The suggested interpretation of the Hammerschmidt decision, i.e., that

47 Observe the wording of this sentence from the Hammerschmidt case: "To conspire to defraud the United States means primarily to cheat the government out of property or money, but it also means to interfere with or obstruct one of its lawful governmental functions by deceit, craft or trickery, or at least by means that are dishonest." See also Denison's dissenting opinion in 287 Fed. 825,826 (C.C.A. 6th 1923).

${ }^{8}$ United States v. Cohn, 270 U.S. 339, 46 Sup. Ct. 251, 70 L.Ed. 616 (r926). 
the second clause of section 37 applies only to dishonest or deceitful conspiracies, seems to be supported to some extent by Fasulo v. United States, ${ }^{49}$ which held that a scheme for obtaining money, by means of intimidation through threats of murder or bodily harm, is not a scheme "to defraud" within section 2I5 punishing the use of the mails for the purpose of executing any "scheme or artifice to defraud." The distinction made in the Hammerschmidt opinion was relied upon, and in effect Horman $v$. United States $^{50}$ seems to have been overruled.

Perhaps we must admit that another limitation upon Haas v. Henkel, has been established. In United States $v$. Winner et al. ${ }^{5 \mathrm{x}}$ heretofore discussed in connection with the first clause of section 37 , there is a holding that a combination to counterfeit a patented article was not a conspiracy "to defraud" the United States under the second clause of section 37; that it did not cheat the United States out of money or property nor interfere with or obstruct one of its lawful governmental functions. The district judge, in sustaining a demurrer to the particular count, admitted that the combination would "defraud the United States of its right to the unimpaired effectiveness of the patent laws"; but argued that to give to section 37 "this broad significance" would violate the "intendment" of the statute and go beyond the import of the decided cases. As to the desirability of this result we express our doubt. The combination appears to have been dishonest and the court stated that it was a deception. True enough the United States was not cheated out of money or property except in the very remote sense that appropriations to sustain the patent system were rendered futile to the extent that this combination was successful. But to impair the effectiveness of the patent laws, as was admitted to be the case, seems to us to interfere with a lawful governmental function. The district judge argued that the government does not undertake "to maintain any administrative function or control over the patented article, its use or disposition, after letters patent are issued"; but a federal statute provided a "qui tam" action for counterfeiting a patent. Is this not enough? Assuming that there is always a stopping place we fail to see why the one chosen in the Winner case is a desirable one. Perhaps, however, the difference in opinion is temperamental, or largely so, and therefore defies reduction by argument.

In conclusion we see no escape for those in our supposed combination,

49 Fasulo v. United States, 272 U.S. 620, 47 Sup. Ct. 2c0, 7 I L.Ed. 443 (I926).

${ }^{50}$ Horman v. United States, Ir6 Fed. 350 (C.C.A. 6 th I902).

sI United States v. Winner et al., 28 F. (2d) 295 (D.C.N.D. Ill. I928). A very recent decision, U.S. v. Terranova et al., 7 F. Supp. 989 (D.C.N.D. Cal. r934), appears to support in some measure the doubts expressed concerning the fraud aspect of U.S. v. Winner et al. 
no matter how desirable their conduct may have seemed to them as men of good conscience, and despite the possibility or even probability of their escape from the clutches of the second clause of section 37 if the combination has acted solely on the basis of an open defiance to obtain what many may think to be needed for the salvation of the country. Section 37 came into the federal laws somewhat modestly but the interpretation of it reminds one of one of our flags during colonial days. A rattlesnake was pictured as ready to strike and the inscription was: "Don't Tread on Me." 